\title{
Dry season prevalence of avian Coccidia infection in domesticated chickens (Gallus domesticus) in Jere Council, Borno State, Nigeria
}

\author{
J. R. Lawal ${ }^{1}$, I. A. Gulani ${ }^{1}$, A. M. Ali ${ }^{1}$, A. M. Bello ${ }^{1}$, F. A. Abadam ${ }^{2}$, M. Mustapha ${ }^{1}$, J. Dauda ${ }^{3}$, L. \\ Adamu ${ }^{1}$ and A. A. Biu ${ }^{4}$ \\ 1Department of Veterinary Medicine, Faculty of Veterinary Medicine, University of Maiduguri, PMB 1069, Maiduguri, \\ Borno State, Nigeria. \\ 2Department of Food Science and Technology, Ramat Polytechnic, PMB 1070, Maiduguri, Borno State, Nigeria. \\ ${ }^{3}$ Department of Veterinary Public Health and Preventive Medicine, Faculty of Veterinary Medicine, University of \\ Maiduguri, PMB 1069, Maiduguri, Borno State, Nigeria.
}

${ }^{4}$ Department of Veterinary Microbiology and Parasitology, Faculty of Veterinary Medicine, University of Maiduguri, PMB 1069, Maiduguri, Borno State, Nigeria.

*Corresponding author. Email: rabanajallailudeen@yahoo.com

Copyright @ 2016 Lawal et al. This article remains permanently open access under the terms of the Creative Commons Attribution License 4.0, which permits unrestricted use, distribution, and reproduction in any medium, provided the original work is properly cited.

Received 21st August, 2016; Accepted 5th October, 2016

\begin{abstract}
The present study was carried out between the months of October, 2014 to April, 2015 and aimed at determining the dry season prevalence of avian coccidia infection and their degree of severity among domesticated chickens (Gallus domesticus) in Jere Council, Borno State, Nigeria. A total of 430 fresh faecal and gut samples were collected from chickens of both exotic and local breeds. The samples were examined using floatation and intestinal impulsion smear techniques. The study was conducted among breeds (exotic vs. local), sexes (male vs. female), ages (young vs. adult), management systems (intensive vs. extensive) and housing (cage vs. deep litter). Out of the 430 faecal samples examined, $54(12.60 \%)$ were positive for various Eimeria species. Infection was more in the exotic $(7.90 \%)$ than the local breed $(4.70 \%)$. Coccidia infection found in young $(10.0 \%)$ was higher $(P=0.0001)$ than in adult chickens $(2.60 \%)$, while female ones had higher $(P=0.03)$ number of coccidia than the males. Chickens reared under poor management system showed higher infection (10.20\%) compared to the good management one (2.30\%). Chickens reared under intensive deep litter housing has higher coccidial load $(9.30 \%)$ than those reared under extensive system $(3.30 \%)$. Eimeria necatrix had the highest degree $(42.60 \%)$ of severity score $(+4)$, followed by Eimeria acervulina $(27.80 \%)$, Eimeria tenella $(24.10 \%)$ and E. maxima $(5.60 \%)$ with degrees of severity scores $+3,+4$ and $(+3)$ respectively. In conclusion, there was presence of coccidia infection in Jere area of Borno State, Nigeria.
\end{abstract}

Key words: Avian coccidia, domesticated chickens, dry season, infection.

\section{INTRODUCTION}

In developing countries poultry production offers an opportunity to feed the fast growing human population and to provide income for farmers. Moreover, poultry in many parts of the world is considered the chief source of not only cheaper protein of animal origin but also of high quality human food (EARO, 2000). Coccidiosis is an important parasitic disease that induces great economic loss particularly in poultry industry (Nematollahi et al., 2009; Bera et al., 2010), and is considered as the most prevalent intestinal parasitic disease of poultry all over 
the world (Oljira et al., 2012; Lawal et al., 2016). The disease is caused by different species of the genus, Eimeria family Eimeridae order Cucoccidioria and phylum Spicomplera (Taylor et al., 2007a, b). In domesticated chickens, at least nine species of Eimeria have been recognized (Gari et al., 2008; Bowman, 2009; Morgan et al., 2009). Eimeria tenella and E. necatrix are the most pathogenic species. Eimeria acervulina, E. maxima and E. mivati are common and moderately pathogenic; $E$. brunetti is uncommon but pathogenic when it does occur. $E$. mitis, E. praecox and E. hagani are relatively nonpathogenic species (Soulsby, 1982; Methusela, 2001; Nematollahi et al., 2008; Jadhav et al., 2011). The infection occurs when susceptible birds ingest feed or water contaminated with sporulated oocysts (Allen and Fetterer, 2002). Clinical signs of the disease is characterized by dysentery, enteritis, emaciation, droopy wings, poor growth, drop in egg production (Rehman et al., 2010; Awais et al., 2012) with high morbidity and mortality rates (Shirzad et al., 2011). Sometimes, due to higher stocking densities of birds and poor management in intensive deep litter systems, its incidence is being increased in poultry (Nnadi and George, 2010; Naphade, 2013). Eimeria spp. is omnipresent and can survive in infected birds and the environment for long times (McDougald, 2003). It causes high mortality in young chicks because most of the Eimeria species affect birds between the age of 3 and 18 weeks (Toulah, 2007; Nematollahi et al., 2008; 2009). Coccidiosis can be controlled by good management including good ventilation, dry and clean litter, cleaning and decontamination of drinkers and feeders, and proper stocking density in poultry farms (Al-Natour et al., 2002; McDougald, 2003; Ashenafi et al., 2004; Al-Quraishy et al., 2009). Recently, there was influx of people into Jere Council of Borno State and the population is in the increase. There is urgent need to increase the supply of animal protein, which could be achieved through the improvement of livestock production especially poultry, in order to meet the immediate human nutritional requirements. However, commercial poultry production reared intensively for meat (broilers) and table eggs (layers) is a growing enterprise in Borno State. Knowledge about the prevalence and importance of avian coccidiosis among commercially reared and backyard poultry system is essential in Borno State. Rainy season had been implicated to aggravate the outbreak of coccidiosis in poultry due to the increase in humidity which favours Eimeria oocyts sporulation (Awais et al., 2012; Ali et al., 2014). However, researches have shown that the disease can occur throughout the year, especially where strict biosecurity measures and good hygiene in deep litter poultry houses are not well maintained. The current study was aimed at determining the dry season prevalence and the degree of infection of avian coccidia among domesticated chickens in Jere Council of Borno State.

\section{MATERIALS AND METHODS}

\section{Study area}

Jere Councils is located in Maiduguri, Borno State Northeastern Nigeria. Maiduguri is the capital and largest city of Borno State, located within the Sahel savannah zone of the Northeastern Nigeria. It lies approximately between $11^{\circ} 5^{\prime}$ and $11.83^{\circ} \mathrm{N}$ latitude and $13^{\circ} 09^{\prime}$ and $13.50^{\circ} \mathrm{E}$ longitude at about $350 \mathrm{~m}(1161 \mathrm{ft})$ above sea level with ambient temperatures of 40 to $45^{\circ} \mathrm{C}$ (http://www.unimaid.edu.ng/About_Maid.aspx). The climate is hot and dry for a greater part of the year with a rainy season from June to September in the Northern part and May to October in the Southern part with a mean annual rainfall and temperature of about $650 \mathrm{~mm}$ and $32^{\circ} \mathrm{C}$, respectively. The mean relative humidity ranges from 30 to $50 \%$ with the minimum usually experienced in the months of February and March, when it drops to as low as $10 \%$ and reaches maximum in August, as high as $90 \%$.

\section{Study Design}

A cross sectional study was designed to estimate the prevalence and degree of severity of avian coccidia infection in chickens of exotic and local breeds of both sexes and various ages. A total of 430 feacal and gut samples were randomly collected from both exotic and local breed chickens from backyard poultry farms located within Mairi area, the University of Maiduguri staff quarters and poultry dressing slab of Custom markets. Samples were collected between the months of October, 2014 to April, 2015.

\section{Sample Size Determination}

The desired sample size for the study was calculated using the equation described by Thrusfield (2005) with 95\% confidence interval, $5 \%$ absolute precision and $50 \%$ expected prevalence as shown below:

$\mathrm{n}=\frac{1.96^{2} \times \mathrm{pq}\left(1-{ }_{-} \mathrm{p} \exp \right)}{\mathrm{I}^{2}}$

Where: $\mathrm{n}=$ the required sample size, $\mathrm{p}=$ expected prevalence, $q=1-p ; l=$ absolute precession.

As a result, 430 study populations were selected.

\section{Sample Collection and Analysis}

Fresh faecal samples were collected from birds. To collect faeces from the gut, birds were slaughtered, the abdomen cut open using a sharp scalpel blade and the 
Table 1. Overall Prevalence of avian coccidia infection.

\begin{tabular}{lcc}
\hline Total Number of feacal Sample Examined & Number of Positive samples & Number of negative samples \\
\hline 430 & 54 & 376 \\
Overall prevalence $(\%)$ & 12.60 & 87.40 \\
\hline
\end{tabular}

Table 2. Prevalence of coccidia infection in breeds, ages and sexes of chickens

\begin{tabular}{llccccc}
\hline Risk Factors & Information & No. examined & No. positive & Prevalence (\%) & $\mathbf{L}-\mathbf{U}$ (95\% Cl) & $\boldsymbol{p}$-value \\
\hline \multirow{2}{*}{ Breed } & Local & 190 & 20 & 4.70 & $0.8568-0.9409$ & \multirow{2}{*}{0.3934} \\
& Exotic & 240 & 34 & 7.90 & $0.8310-0.9126$ & \\
\multirow{2}{*}{ Age } & Young & 130 & 43 & 10.0 & $0.6806-0.8137$ & $<0.0001$ \\
\multirow{2}{*}{ Sex } & Adult & 300 & 11 & 2.60 & $0.9377-0.9822$ & \\
& Male & 245 & 22 & 5.10 & $0.8780-0.9477$ & 0.0343 \\
\hline
\end{tabular}

intestine gently removed. Intact faeces samples were then squeezed out into sterile sample bottles. All samples were properly labeled and transported immediately after collection to the laboratory. Factors that were noted during sampling included age, sex, breed of birds and management practice on farms.

Samples were processed and analyzed in the Parasitology unit, Department of Veterinary Medicine Research Laboratory, Faculty of Veterinary Medicine, University of Maiduguri, Nigeria. In the laboratory each faecal sample was gently macerated in potassium dichromate solution at $37^{\circ} \mathrm{C}$ using mortar and pestle. The suspension was filtered through a muslin cloth and allowed to sediment. The supernatant was discarded and the oocysts in the sediment were separated by floatation method in saturated sodium chloride solution. They were examined microscopically and the different Eimeria species were identified on the basis of shape and size of sporocysts and sporozoites as described by Bowman and Georgis (2003).

\section{Data analysis}

The data generated from this study were analyzed using SPSS version-17 statistical software. Pearson's Chi square test was used to measure statistical significance of results. Results were considered to be statistically significant at $95 \%$ Confidence Interval and $p$-value < 0.05 .

\section{RESULTS}

Out of the 430 faecal and gut samples collected and examined microscopically for the presence of coccidial parasites during the dry season period, $54(12.60 \%)$ was positive for coccidian infection (Table 1).
Considering the prevalence among the breed of chickens examined, infection was found to be more in the exotic chickens $(7.90 \%)$ compared to the local chickens $(4.70 \%)$. Athough, association among the breeds of chickens was not significant $(P=0.3934)$. Infection was found to occur significantly $(P<0.0001)$ more in the young chickens $(10.0 \%)$ than in the adult chickens $(2.60 \%)$. Also, significant $(P=0.03)$ infection was found to occur more in female chickens $(7.40 \%)$ compared to the male ones $(5.10 \%)$ as shown in Table 2.

Considering the prevalence of avian coccidia according to management systems, it was found that chickens reared under poor management system (10.20\%) significantly $(P<0.0001)$ showed high infection compared to those reared under a good management system $(2.30 \%)$. However, considering the prevalence of avian coccidia according to type of housing in which chickens examined were reared, showed that chickens reared in cages under intensive housing have significantly $(P=$ $0.02)$ higher percentage of infection $(9.30 \%)$ compared to those reared under extensive housing or no house (3.30\%) (Table 3).

Out of 54 infected chickens, infection by Eimeria necatrix $(42.60 \%)$ which was found in the jejunum had degree of severity score $(+4)$, followed by $E$. acervulina $(27.80 \%)$ in the duodenum and E. tenella $(24.10 \%)$ in the caecum which had degree of severity scores of +3 and +4 respectively. Eimeria maxima $(5.60 \%)$ which was found in the ileum had degree of severity score $(+3)$ (Table 4).

\section{DISCUSSION}

Coccidiosis is considered the most prevalent intestinal parasitic disease in commercial chicken production system worldwide. The results of this present study shows that in dry season chickens could be infected by 
Table 3. Effect of management system on prevalence of avian coccidia infection.

\begin{tabular}{llccccc}
\hline Parameters & Type & $\begin{array}{c}\text { No. of samples } \\
\text { examined }\end{array}$ & $\begin{array}{c}\text { No. of } \\
\text { positive }\end{array}$ & Prevalence \% & L - U (95\% Cl) & p-value \\
\hline \multirow{3}{*}{ Management System } & Poor & 105 & 44 & 10.20 & $0.6246-0.7764$ & $<0.0001$ \\
& Good & 325 & 10 & 2.30 & $0.9459-0.9856$ & \\
Housing type & Intensive & 240 & 40 & 9.30 & $0.8102-0.8957$ & 0.0157 \\
\hline
\end{tabular}

Management system: Poor (Inappropriate; wet and damp litter/ inadequate ventilation); Good (appropriate; dry litter/adequate ventilation).

Table 4. Eimeria species found in gut of chickens.

\begin{tabular}{lcclc}
\hline Coccidia species & $\begin{array}{c}\text { No. of samples } \\
\text { examined }\end{array}$ & No. positive (\%) & $\begin{array}{l}\text { Region of Intestine } \\
\text { Affected }\end{array}$ & $\begin{array}{c}\text { Severity scores of } \\
\text { infection }\end{array}$ \\
\hline Eimeria tenella & 54 & $13(24.10)$ & Caecum & $4+$ \\
Eimeria necatrix & 54 & $23(42.60)$ & Jejunum & $4+$ \\
Eimeria acervulina & 54 & $15(27.80)$ & duodenum & $3+$ \\
Eimeria maxima & 54 & $3(5.60)$ & lleum & $3+$ \\
Overall & $54(100)$ & & \\
\hline
\end{tabular}

Eimeria species. The finding of this study is similar to those reported by Awais et al. (2012) and Bachaya et al. (2015) who also recorded peak coccidiosis infection in chickens between the months of November and January in Pakistan. This can be attributed to the harsh dry cold harmattan weather which can be implicating in immunosuppression and predisposition of avian species to wide range of infectious diseases including coccidiosis. Adamu et al. (2009) and Abalaka et al. (2013) have reported high incidence of poultry diseases with high recorded cases of coccidiosis in poultry during the dry season in Sokoto State, Nigeria. Bachaya et al. (2012) reported that coccidiosis in domesticated chickens occurred all around the year, but the intensity was higher in the rainy season. The $12.60 \%$ overall prevalence recorded in this study was lower than the prevalence of $31.80 \%$ in Maiduguri by Lawal et al. (2016). The occurrence was attributed to poor management systems especially allowing rampart water spillages on litter. There have been varying reports of prevalence of coccidiosis among chickens from some parts of Nigeria, Grema et al. (2014) recorded (11.40\%) in Gombe; $31.80 \%$ was reported by Lawal et al. (2016) in Maiduguri, Muazu et al. (2008) recorded $89.50 \%$ in Vom, Plateau State, $34.10 \%$ was recorded by Barde et al. (2012) in Kaduna, $36.60 \%$ in Benin by Dakpogan and Salifou (2013), Adamu et al. (2009) and Jatau et al. (2012) recorded the overall prevalence of coccidiosis of $14.0 \%$ and $33.30 \%$ in Zaria and Sokoto respectively.

Higher incidence of coccidiosis in exotic chickens compared to local ones observed could be linked to the fact that the exotic chickens were reared in confinement and were likely to be most exposed to the infective stages of the organism in litters and feeds while the local breeds of chickens were usually found roaming and scavenging around the surroundings. They may not come into contact with the infection or may not ingest the infective stages of the organism. This agrees with the findings of Jatau et al. (2012); Oljira et al. (2012) and Garbi et al. (2015) who also reported high prevalence of coccidian infection in exotic breed chickens as compared to the free range local chickens. However, the findings of this current study did not corroborates previous reports by Benisheikh et al. (2013) who reported higher coccidiosis rate in local chickens $(38.8 \%)$ than in exotic breeds (22.8\%). Moreso, Ashenafi et al. (2004) in Ethiopia and Hadipour et al. (2013) in Iran have reported high incidence of avian coccidiosis in indigenous scavenging chickens.

Higher occurrence of coccidial infection in younger chickens $(10.0 \%)$ as compared to adults $(2.6 \%)$ showed that coccidial infection is age related. The difference in age variation among birds could be due to the effect of age susceptibility. Adult birds could have developed acquired immunity to infection due to previous repeated contacts with several coccidia species in the litter, that can enable them to harbor the infection without showing clinical signs whereas young birds may not have developed full immunity and can be more vulnerable and experience great mortality where outbreak of the disease occur (Chapman et al., 2005; 2011; Györke et al., 2013). This finding is in concurrence with previous report of Muazu et al. (2008) who reported $36.7 \%$ prevalence of coccidial infection among adult birds and $52.9 \%$ among 
the younger birds. Moreover, Oljira et al. (2012), Bachaya et al. (2012), Ali et al. (2014) and Lawal et al. (2016) have also reported the predominance of coccidial infection among young birds as compared to adult birds. The finding of this present study was not consistent with those of Dakpogan and Salifou (2013) who reported higher rate in adult chickens (40.70\%) as compared to the young ones (28.20\%). Moreover, high rate of infection in adult chickens as compared to younger ones have also been reported by Ahmed et al. (2003), Amer et al. (2010) and Bachaya et al. (2015).

In this current study, coccidial infection was found to occur more in females $(7.40 \%)$ than in male chickens $(5.10 \%)$. The association between the sexes was statistically significant $(P=0.03)$. This finding agrees with those of Oljira et al. (2012) who also reported higher frequency of avian coccidiosis in female chickens $(21.43 \%)$ as compared to male ones (19.38\%). Although, Olanrewaju and Agbor (2014) have recorded high prevalence of coccidiosis among male chickens (80.0\%) as compared to females (70.0\%). Garbi et al. (2015) have also reported higher prevalence of coccidiosis in male $(20.0 \%)$ chickens as compared to the female $(19.27 \%)$.

Chickens reared under poor management system $(10.20 \%)$ in the study area shows high frequency of infection compared to those reared under a good management system $(2.30 \%)$. The association between the management systems was statistically significant $\left(P_{<}\right.$ $0.0001)$. Many researches have reported the implication of management systems on chickens' productivity, disease occurrence and susceptibility of intensively reared chickens (Geidam et al., 2011, Elelu et al., 2012; Hadipour et al., 2013). More so, management of poultry houses plays a significant role in the spread of coccidiosis because coccidial oocysts are ubiquitous and are easily spread in the poultry house environment. Furthermore, due to Eimeria species high sporulation potential, it is usually very complex to control coccidia in chickens reared on deep litter system under intensive management conditions (Adhikari et al., 2008). Poor management systems, such as allowing water spillage in poultry house to wet litter that encourages oocyst sporulation, contamination drinkers and feeders by feaces, bad ventilation, and high stocking density, can worsen the clinical manifestation of coccidiosis (AlQuraishy et al., 2009; Sharma et al., 2013; Lawal et al., 2016).

However, it was found that chickens caged and reared under intensive deep litter housing $(9.30 \%)$ in the study area shows high frequency of infection than those in extensive type or no house $(3.30 \%)$. The association between the housing types was statistically significant $(P=0.02)$. This could be connected with fact that birds under intensive housing could possibly get regular infection with coccidia whenever they feed on litters contaminated with sporulated Eimeria oocytes (Methusela et al., 2002; Taylor et al., 2007a, b). This finding is also consistent with previous reports of Lunden et al. (2010) and Dakpogan and Salifou (2013) which stated that relatively higher prevalence of coccidiosis in birds could be ascribed to the confinement and deep litter-based rearing system compared to birds in cages.

Among the 54 infected chickens, Eimeria necatrix $(42.60 \%)$ in the jejunum with degree of severity score (+4) was most frequent, followed by Eimeria acervulina $(27.80 \%)$ in the duodenum and Eimeria tenella $(24.10 \%)$ in the caecum with degrees of severity score +3 and +4 respectively. Eimeria maxima $(5.60 \%)$ found in the ileum was the least frequent Eimeria spp. in the examined chickens with degree of severity score $(+3)$. This present study recorded four Eimeria species in the infected chickens. The results agree with the type of Eimeria species reported by Khan et al. (2006), Hadipour et al. (2011), Awais et al. (2012), Bachaya et al. (2012) and Bachaya et al. (2015). The degree of severity of coccidiosis reported in this study supported the findings of Dalloul and Lillehoj (2006) and Benisheikh et al. (2013) who have stated that Eimeria tenella and Eimeria necatrix are the most pathogenic Eimeria species in infected birds but Eimeria acervulina and Eimeria maxima are common and slightly to moderately pathogenic. Although, it has already been reported that Eimeria species and their prevalence vary greatly within different geographical areas of the world (Györke et al., 2013; Zhang et al., 2013).

\section{Conclusions}

In conclusion, the present study showed that infection of different species of coccidia occurred in dry season and was found to be more in exotic, female and young birds. Poor managed and intensively reared birds accumulated more coccidia in their gut.

\section{CONFLICT OF INTEREST}

The authors declare that they have no conflict of interest.

\section{REFERENCES}

Abalaka, G. O., Mkpado, M., \& Ugwu, S. O. C. (2013). Rearing methods, seasons of the year and survivability of rural poultry enterprise in Nigeria. Journal of Agriculture and Sustainability, 3(1), 27-55.

Adamu, A. Y., Ahmed, A. B., Abubakar, M. B., \& Lawal, M. D. (2009). A retrospective study (2004-2008) of poultry diseases diagnosed in Veterinary Teaching Hospital, Usmanu Danfodiyo University Sokoto and Sokoto Veterinary Centre, Sokoto State, Nigeria. International Journal of Animal and Veterinary Advances, 1(1), 15-17.

Adhikari, A., Gupta, R., \& Pant, G. R. (2008). Prevalence and identification of coccidian parasite (Eimeria spp.) in layer 
chicken of Ratnanagar Municipality, Chitwan district, Nepal. Journal of Natural History Museum, 23, 45-50.

Ahmed, N. E., Negm Eldin, M. M., El Akabawy. L. M., \& El.Medawy, R. S. (2003). Incidences of some protozoan parasites in birds. Kafr El-Sheikh Veterinary Medicine Journal, 1(1), 235-251.

Ali, H., Naqvi, F., \& Tariq, N. (2014). Prevalence of coccidiosis and its association with risk Factors in poultry of Quetta, Pakistan. Asian Journal of Applied Sciences, 2(4), 554-558.

Allen, P. C., \& Fetterer, R. H. (2002). Recent advances in biology and immunology of Eimeria species and in diagnosis and control of infection with coccidian parasites of poultry. Clinical Microbiology, 15, 58-65.

Al-Natour, M. Q., Suleiman, M. M., \& Abo-Shehadab, M. N. (2002). Flock-level prevalence of Eimeria species among broiler chicks in northern Jordan. Preventive Veterinary Medicine, 53, 305-310.

Al-Quraishy, S., Abdel-Baki, A. S and Dkhil, M. A. (2009). Eimeria tenella infection among broiler chicks Gallus domesticus in Riyadh city, Saudi Arabia. Journal of King Saud University of Sciences, 21, 191-193.

Amer, M. M., Awaad, M. H. H., Rabab, M. El-Khateeb, Nadia, M. T. N. Abu-Elezz, A. Sherein-Said, Ghetas, M. M., \& Kutkat, M. A. (2010). Isolation and identification of Eimeria from field coccidiosis in chickens. Journal of American Science, 6(10), 1107-1114.

Ashenafi, H., Tadesse, S., Medhin, G., \& Tibbo, M. (2004). Study on coccidiosis of scavenging indigenous chickens in central Ethiopia. Tropical Animal Health and Production, 36, 693-701.

Awais, M. M,, Akhtar, M., lqbal, Z., Muhammad, F., \& Anwar, M. I. (2012). Seasonal prevalence of coccidiosis in industrial broiler chickens in Faisalabad, Punjab, Pakistan. Tropical Animal Health and Production, 44, 323-328.

Bachaya, H. A., Abbas, R. Z., Raza, M. A., Iqbal, Z., Rehman, T. U., Baber, W. and Hussain, R. (2015). Existence of coccidiosis and associated risk factors in broiler chickens in Southern Punjab, Pakistan. Pakistan Veterinary Journal, 35(1), 81-84.

Bachaya, H. A., Raza, M. A., Khan, M. N., Iqbal, Z., Abbas, R. Z., Murtaza, S., \& Badar, N. (2012). Predominance and detection of different Eimeria species causing coccidiosis in layer chickens. The Journal of Animal and Plant Sciences, 22(3), 597-600

Barde, J. I., Garba, A., Gashua, M. M., Talba, M. A., Gugong, V. T., Sa'adatu, I., Owada, A. H., Konzing, L., Awulu, S. J. and Mohammed, M. N. (2012). Common diseases of poultry in Kaduna State. Nigerian Veterinary Journal, 33(3), 581-585.

Benisheikh, A. A. G., Tom, I., Thamus, Z. Y., Sanda, K. A., \& Biu. A. A. (2013). Comparative studies on the prevalence of coccidiosis in indigenous (Gallus gallus domesticus) and exotic breeds (layers) in Benisheikh town, Borno State. Journal of Medical and Applied Biosciences, 5(2), 33-37.

Bera, A. K., Bhattacharyaa, D., Pana, D., Dharab, A., Kumarc, S. and Das, S. K. (2010). Evaluation of economic losses due to coccidiosis in poultry industry in India. Agricultural Economics Research Review, 23, 91-96.

Bowman, D., \& Georgis, D. (2003). Parasitology for Veterinarians. $5^{\text {th }}$ ed.; Saunders, U.S.A, pp. 324-345.

Bowman, D., (2009). Georges parasitology for Veterinarians. $9^{\text {th }}$ ed. Saunders Elsevier, India, pp. 2 -94.

Chapman, H. D., Matsler, P. L., Muthavarapu, V. K., \& Chapman, M. E. (2005). Acquisition of immunity to Eimeria maxima in newly hatched chickens given 100 oocysts. Avian Disease, 49(3), 426-429.

Dakpogan, H. B., \& Salifou, S. (2013). Coccidiosis prevalence and intensity in litter based high stocking density layer rearing system of Benin. Journal of Animal and Plant Sciences, 17(2), $2522-2526$.

Dalloul, R. A., \& Lillehoj, H. S. (2006) Poultry coccidiosis. Recent advancements in control measures and vaccine development. Expert Revised Vaccines, 5(3), 143-162.

EARO (2000). Animal science research strategy directorate. Poultry research strategy. Addis Ababa, July, pp. 1-33.

Elelu, N., Jaji, Z., Badiru, A., Olowoleni. F., \& Ambali, A. G. (2012). Assessment of management and health practices in some selected poultry establishments in Ilorin, Kwara State, Nigeria. International Journal of Poultry Science, 11(8), 524528.

Garbi, F., Tesfaye, A., \& Woyessa, M. (2015). Study on prevalence of poultry coccidiosis in Nekemte town, East Wollega, Ethiopia. African Journal of Agricultural Research, 10(5), $238-333$.

Gari, G., Tilahun, G., \& Dorchies, P. H. (2008). Study on poultry coccidiosis in Tiyo district, Arsi zone, Oromia regional State, Ethiopia. International Journal of Poultry Science, 7, 251-256.

Geidam, Y. A., Rabana, J. L., Sanda, K. A., \& Grema, H. A. (2011). Survey of health and management problems associated with rural poultry production in Gombe metropolis, North-eastern Nigeria. Sahel Journal of Veterinary Sciences, 10(2), 77-81.

Grema, H. A., Suleiman, A., Rabana, J. L., \& Geidam, Y. A. (2014). A six year $(2005-2010)$ retrospective study of avian coccidiosis diagnosed in Gombe veterinary clinic, Nigeria. Sokoto Journal of Veterinary Sciences, 12(2), 8-13.

Györke, A., Pop, L., \& Cozma, V. (2013). Prevalence and distribution of Eimeria species in broiler chicken farms of different capacities. Parasite, 20, 50.

Hadipour, M. M., Olyaie, A., Naderi, M., Azad, F., \& Nekouie, O. (2013). Prevalence of Eimeria species in scavenging native chickens of Shiraz, Iran. African Journal of poultry farming, 1(2), 34-36.

Jadhav, B. N., Nikam, S. V., Bhamre, S. N., \& Jaid, E. L. (2011). Study of Eimeria necatrix in broiler chicken from Aurangabad District of Maharashtra state India. International Multidisciplinary Research Journal, 1, 11-12.

Jatau, I. D., Sulaiman, N. H., Musa, I. W., Lawal, A. I., Okubanjolsah, O. O., \& Magaji, Y. (2012). Prevalence of coccidia infection and preponderance Eimeria species in free range indigenous and intensively managed exotic chickens during hot-wet season, in Zaria, Nigeria. Asian Journal of Poultry Science, 6, 79-88.

Khan, M. Q., Irshad, H., Anjum, R., Jahangir, M., \& Nasir, U. (2006). Eimeriosis in Poultry of Rawalpindi/lslamabad Area. Pakistan Veterinary Journal, 26, 85-87.

Lawal, J. R., Jajere, S. M., Ibrahim, U. I., Geidam, Y. A., Gulani, I. A., Musa, G. and lbekwe, B. U. (2016). Prevalence of coccidiosis among village and exotic breed of chickens in Maiduguri, Nigeria. Veterinary World, 9(6), 653-659.

Lunden, A., Thebo, P., Gunnarson, S., Hooshmand- Rad, P., Tauson, R., \& Uggla, A. (2010). Eimeria infections in litterbased, high stocking density systems for loosehoused laying hens in Sweden. British Poultry Science, 41(4), 440-447.

McDougald, L. R. (2003). Coccidiosis. In Diseases of Poultry. $11^{\text {th }}$ ed. lowa State Press, Blackwell Publishing Company, USA. Pp. 974-991. 
Methusela, S. (2001). Studies on prevalence and economic impacts of poultry coccidiosis in different production systems in Debre Zeit and Addis Ababa Ethiopia. MSc thesis, Faculty of Veterinary Medicine, Free University of Berlin, Debre Zeit/Berlin.

Methusela, S. K., Tilahun, G., Hafez, H. M., \& Wolemesked, M. (2002). Studies on poultry coccidiosis in different production systems in Debre Zeit and surrounding areas, Ethiopia. Bulletin of Animal Health and Production in Africa, 50, 41-52.

Morgan, J. A., Morri, G. M., Wlodek, B. M., Byrne, R., Jenner, M., Constantinoiu, C. C., Anderson, G. R., Lew-Tabor, A. E., Molloy, J. B., Gasser, R. B., \& Jorgensen, W. K. (2009). Realtime polymerase chain reaction (PCR) assays for the specific detection and quantification of seven Eimeria species that cause coccidiosis in chickens. Molecular and Cellular Probes, 23, 83-89.

Muazu, A., Masdooq, A. A., Ngbede, J., Salihu, A. E., Haruna, G., Habu, A. K., Sati, M. N. and Jamilu, H. (2008). Prevalence and identification of species of Eimeria causing coccidiosis in poultry within Vom, Plateau State, Nigeria. International Journal of Poultry Science, 7, 917-918.

Naphade, S. T. (2013). Studies on the incidence of infection of the disease coccidiosis in broiler chickens from in and around Aurangabad City. Indian Journal of Scientific Research and Technology, 1(3), 39-43.

Nematollahi, A, Moghaddam, G. H., \& Farshbaf Pourabad, R. (2009). Prevalence of Eimeria species among broiler chicks in Tabriz (Northwest of Iran). Munis Entomology and Zoology, 4, 53-58.

Nematollahi, A., Moghaddam, G. H., \& Niyazpour, F. (2008). Prevalence of Eimeria spp among Broiler chicks in Tabriz (Northwest of Iran). Research Journal of Poultry Sciences, 2, 72-74.

Nnadi, P. A., \& George, S. O. (2010). A Cross-Sectional Survey on Parasites of Chickens in Selected Villages in the Subhumid Zones of South-Eastern Nigeria. Journal of Parasitology Research, 141, 1-6.

Olanrewaju, C. A., \& Agbor, R. Y. (2014) Prevalence Of Coccidiosis Among Poultry Birds Slaughtered At Gwagwalada Main Market, Abuja, FCT, Nigeria. The International Journal of Engineering and Science, 3(1), 41-45.

Oljira, D., Melaku, A., \& Bogale, B. (2012). Prevalence and Risk Factors of Coccidiosis in Poultry Farms in and Around Ambo Town, Western Ethiopia. American-Eurasian Journal of Scientific Research, 7(4), 146-149.
Rehman, T. U., Khan, M. N., Sajid, M. S., Abbas, R. Z., Arshad, M., Iqbal, Z. and lqbal, A. (2010). Epidemiology of Eimeria and associated risk factors in cattle of district Toba Tek Singh. Pakistan Journal of Parasitology Research, 108, 11711177.

Sharma, S., lqbal, A., Azmi, S., \& Shah, H. A. (2013). Study of poultry coccidiosis in organized and backyard farms of Jammu region. Veterinary World, 6(8), 467-469.

Shirzad, M. R., Seifi, S., Gheisari, H. R., Hachesoo, B. A., Habibi, H., \& Bujmehrani, H. (2011). Prevalence and risk factors for subclinical coccidiosis in broiler chicken farms in Mazandaran province, Iran. Tropical Animal Health and Production, 43, 1601-1604.

Soulsby, E. J. L. (1982). Helminths, Arthropods and Protozoan's of Domesticated Animals, 7th edition. Bailliere Tindall, London, pp. $345-349$.

Taylor, M. A., Coop, R. L., \& Wall, R. L. (2007a). Parasites of poultry and Game Birds. International Veterinary Parasitology, Anderson, J.M. and Macfadyen (Eds.). lowa State, Blackwell Publishing, USA. pp. 459-557.

Taylor, M. A., Coop, R. L., \& Wall, R. L. (2007b). Veterinary Parasitology, $3^{\text {rd }}$ ed. Black Well Publishing, Oxford, UK, Pp. 475-483.

Thrusfield, M. (2005). Survey in Veterinary Epidemiology. 2nd ed. USA: Blackwell Science, Limited, Cambridge, USA, Pp. 178-198.

Toulah, F. H. (2007). Prevalence and comparative morphological studies of four Eimeria spp. of sheep in Jeddah area, Saudi Arabia. Journal of Biological Sciences, 7, 413416.

Zhang, J. J., Wang, L. X., Ruan, W. K., \& An, J. (2013). Investigation into the prevalence of coccidiosis and maduramycin drug resistance in chickens in China. Veterinary Parasitology, 191, 29-34. 